\title{
Profiling the Built-in Electrical Potential in III-V Multijunction Solar Cells
}

Conference Paper NREL/CP-520-39883

May 2006

\section{Preprint}

C.-S. Jiang, D.J. Friedman, H.R. Moutinho, and M.M. Al-Jassim

Presented at the 2006 IEEE $4^{\text {th }}$ World Conference on Photovoltaic Energy Conversion (WCPEC-4)

Waikoloa, Hawaii

May 7-12, 2006

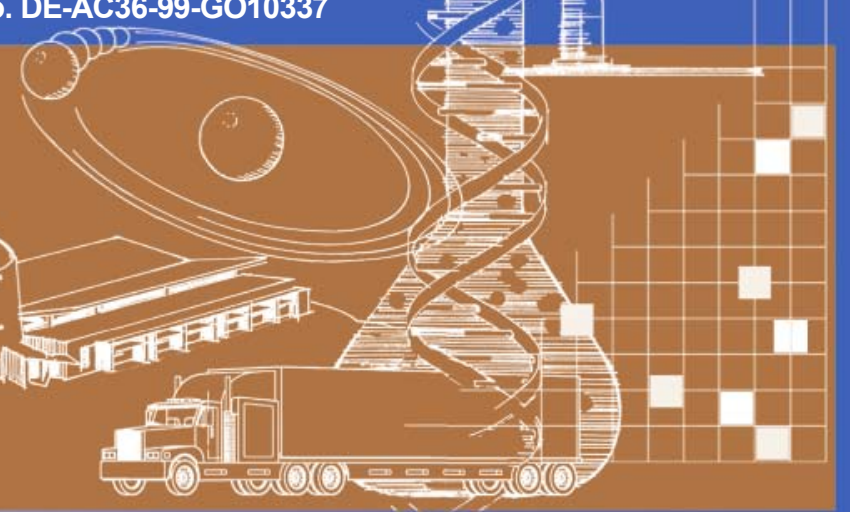




\section{NOTICE}

The submitted manuscript has been offered by an employee of the Midwest Research Institute (MRI), a contractor of the US Government under Contract No. DE-AC36-99G010337. Accordingly, the US Government and MRI retain a nonexclusive royalty-free license to publish or reproduce the published form of this contribution, or allow others to do so, for US Government purposes.

This report was prepared as an account of work sponsored by an agency of the United States government. Neither the United States government nor any agency thereof, nor any of their employees, makes any warranty, express or implied, or assumes any legal liability or responsibility for the accuracy, completeness, or usefulness of any information, apparatus, product, or process disclosed, or represents that its use would not infringe privately owned rights. Reference herein to any specific commercial product, process, or service by trade name, trademark, manufacturer, or otherwise does not necessarily constitute or imply its endorsement, recommendation, or favoring by the United States government or any agency thereof. The views and opinions of authors expressed herein do not necessarily state or reflect those of the United States government or any agency thereof.

Available electronically at http://www.osti.gov/bridge

Available for a processing fee to U.S. Department of Energy and its contractors, in paper, from:

U.S. Department of Energy

Office of Scientific and Technical Information

P.O. Box 62

Oak Ridge, TN 37831-0062

phone: 865.576 .8401

fax: 865.576 .5728

email: mailto:reports@adonis.osti.gov

Available for sale to the public, in paper, from:

U.S. Department of Commerce

National Technical Information Service

5285 Port Royal Road

Springfield, VA 22161

phone: 800.553 .6847

fax: 703.605.6900

email: orders@ntis.fedworld.gov

online ordering: http://www.ntis.gov/ordering.htm 


\title{
PROFILING THE BUILT-IN ELECTRICAL POTENTIAL IN III-V MULTIJUNCTION SOLAR CELLS*
}

\author{
C.-S. Jiang, D. J. Friedman, H. R. Moutinho, and M.M. Al-Jassim \\ National Renewable Energy Laboratory (NREL), 1617 Cole Blvd., Golden, CO 80401
}

\begin{abstract}
We report on a direct measurement of the electrical potential on cross-sections of $\mathrm{GalnP}_{2} / \mathrm{GaAs}$ multiplejunction solar cells by using an ultrahigh-vacuum scanning Kelvin probe microscope (UHV-SKPM). The UHV-SKPM allows us to measure the potential without air molecules being adsorbed on the cross-sectional surface. Moreover, it uses a GaAs laser with photon energy of 1.4 $\mathrm{eV}$ for the atomic force microscope (AFM) operation. This eliminated the light-absorption-induced bottom-junction flattening and top-junction enhancement, which happened in our previous potential measurement using a $1.85-\mathrm{eV}$ laser for the AFM operation. Three potentials were measured at the top, tunneling, and bottom junctions. Values of the potentials are smaller than the potentials in the bulk. This indicates that the Fermi level on the UHV-cleaved (110) surface was pinned, presumably due to defects upon cleaving. We also observed higher potentials at atomic steps than on the terraces for both $\mathrm{GalnP}_{2}$ epitaxial layer and $\mathrm{GaAs}$ substrate. Combining scanning tunneling microscopy (STM) and SKPM measurements, we found that the potential height at steps of the GaAs substrate depends on the step direction, which is probably a direct result of unbalanced cations and anions at the steps.
\end{abstract}

\section{INTRODUCTION}

The built-in electrical potential in junctions of solar cells plays a critical role in photovoltaic action, because it collects photo-excited carriers and is a key factor in determining the open-circuit voltage of solar cell devices. To characterize the built-in potential, we have established a nanometer-scale measurement technique of SKPM [1], and applied the technique to profiling the electrical potential distributions in junctions of III-V, Cu(In,Ga)Se ${ }_{2}$, and hydrogenated amorphous silicon solar cells [1-5]. These potential measurements have improved our understanding of device physics in the solar cells, and provide us a direct method to assess the quality of the p$n$ junctions. We have recently observed a widening and movement of the junction in a III-V space cell upon proton irradiation [6]. The SKPM technique is based on a noncontact AFM (NC-AFM) [7,8], and it measures the electrical potential on sample surfaces. When we measure a potential profile in the junction, we cleave the solar cell samples and expose the junction on crosssections for the potential measurements.

Previously, we have reported the potential measurement on the III-V multijunction cells by using the SKPM based on an air-AFM, in which air molecule adsorption on the cross-sectional surface affected the surface charge and surface potential distributions [1,2]. Moreover, our air-AFM setup uses a laser beam with photon energy of $1.85 \mathrm{eV}$ for the AFM operation. Absorption of the laser light by the solar cell samples was not avoidable in the SKPM measurement, because 1.85 $\mathrm{eV}$ is larger than the bandgaps of most photovoltaic materials. In this paper, we will report on the potential measurement on the III-V cell by using a UHV-SKPM. Moreover, because the UHV-AFM uses a laser with photon energy of $1.4 \mathrm{eV}$, the effect of light absorption was avoided.

\section{MEASUREMENT TECHNIQUE}

SKPM is based on NC-AFM. Because the resonant oscillation peak of the AFM cantilever is super sharp in vacuum (several $\mathrm{Hz}$ ), frequency modulation that sets the frequency shift constant is used for the AFM feedback control (Fig. 1), instead of amplitude-modulation mode

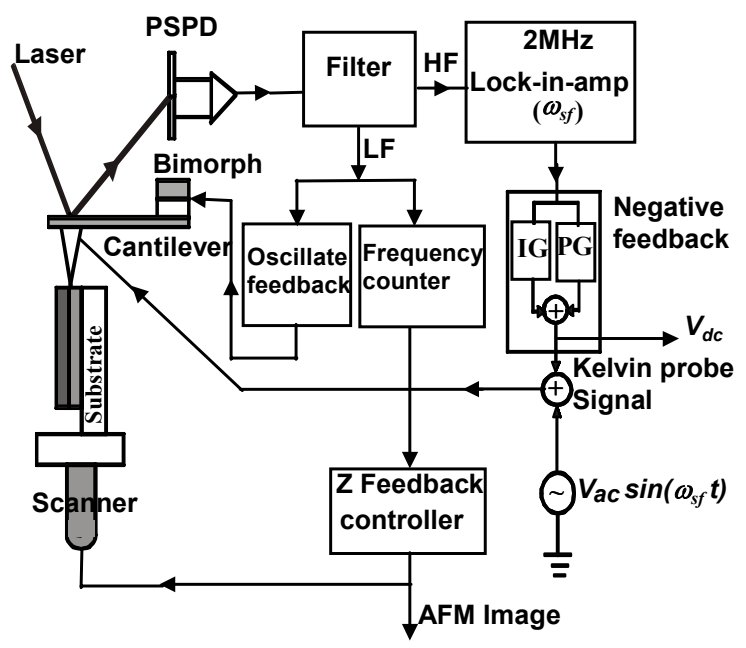

Fig. 1. A schematic of the UHV-AFM and SKPM setup.

*This work has been authored by an employee or employees of the Midwest Research Institute under Contract No. DE-AC36-99GO10337 with the U.S. Department of Energy. The United States Government retains and the publisher, by accepting the article for publication, acknowledges that the United States Government retains a non-exclusive, paidup, irrevocable, worldwide license to publish or reproduce the published form of this work, or allow others to do so, for United States Government purposes. 
used in the air-AFM. For the Kelvin probe, a highfrequency ac voltage $(\sim 400 \mathrm{kHz})$ at the second resonant frequency of the cantilever $\left[V_{a c} \sin \left(\omega_{s r} t\right)\right.$ in Fig. 1] is employed, instead of an off-peak low frequency that is used in the air-SKPM. This second resonant frequency enhances the energy resolution from $\sim 50 \mathrm{mV}$ of the airSKPM to $\sim 10 \mathrm{mV}$ of the UHV-SKPM. The cantilever oscillation signal is separated to low- and high-frequency components by low- and high-pass filters, and these components are sent to the topographic and the Kelvin probe detection circuits, respectively. Comparing the airSKPM, advantages of the UHV-SKPM are: (a) it keeps the fresh cross-sectional surface free of air molecule adsorption; (b) it uses a GaAs laser with a smaller photon energy of $1.4 \mathrm{eV}$ for the AFM operation; and (c) energy resolution is improved. However, a disadvantage of the UHV-SKPM is that with the NC-AFM it is difficult to image a relatively rough thin-film surface with corrugations larger than $\sim 50 \mathrm{~nm}$, because it uses the frequencymodulation mechanism for z-feedback control.

\section{RESULTS AND DISCUSSIONS}

Figure 2 shows a SKPM potential and the corresponding AFM topographic images taken on the cross-section of the $\mathrm{GalnP}_{2} / \mathrm{GaAs}$ tandem-junction cell. Because the potential distribution along the vertical direction is uniform, we averaged the potential along the direction and display the potential profile in Fig. 2(c). The profile shows three potential variations: the $p-n$ junction at the top cell, the tunnel junction, and the p-n junction at the bottom cell. We note that this potential profile is different from the profile we previously measured in air on the same sample, where the 1.85-eV laser light was absorbed by the bottom cell, and the light absorption induced a potential flattening at the bottom junction and a potential enhancement at the top junction [1]. The potential measured by the air-SKPM is away from the

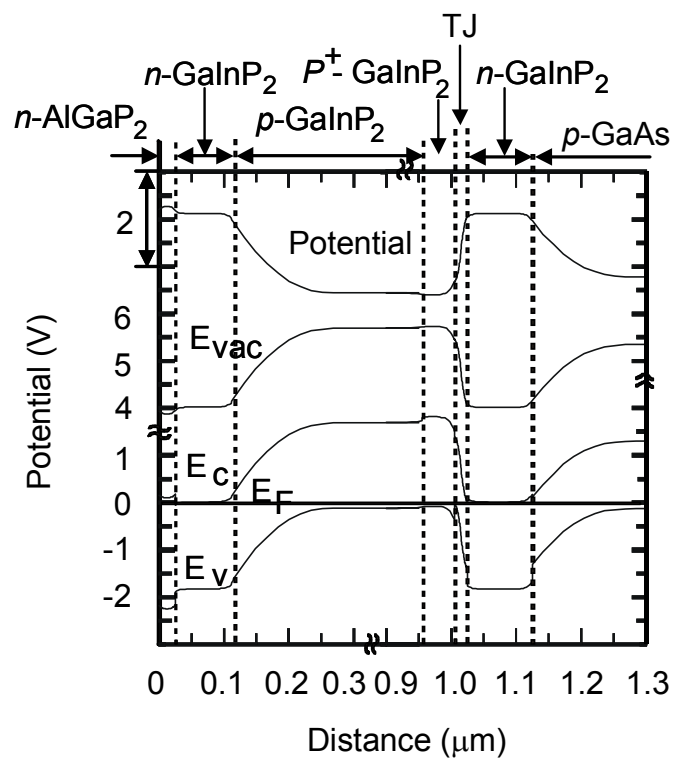

Fig. 3. A calculated band diagram in the bulk of Galn $\mathrm{P}_{2} / \mathrm{GaAs}$ tandem-junction cell by solving Poisson's equation and using parameters of band offsets and bandgaps in the literature.

thermal equilibrium state. However, in the UHV-SKPM measurement, because the bandgap of the bottom cell approximately equals the photon energy, the effect of the laser light absorption should be weak or negligible. In this case, the sample is close to the thermal equilibrium state.

The band diagram (Fig. 3) in the bulk of the tandem cell is calculated by solving Poisson's equation and using parameters of band offsets and bandgaps listed in Table 1 [9-16]. There are three main potentials at the top, tunneling, and bottom junctions. The big potential drop at the top junction is close to the value of the $\mathrm{GalnP}_{2}$ bandgap $(\sim 1.8 \mathrm{eV})$. The potential increase $(1.56 \mathrm{eV})$ in

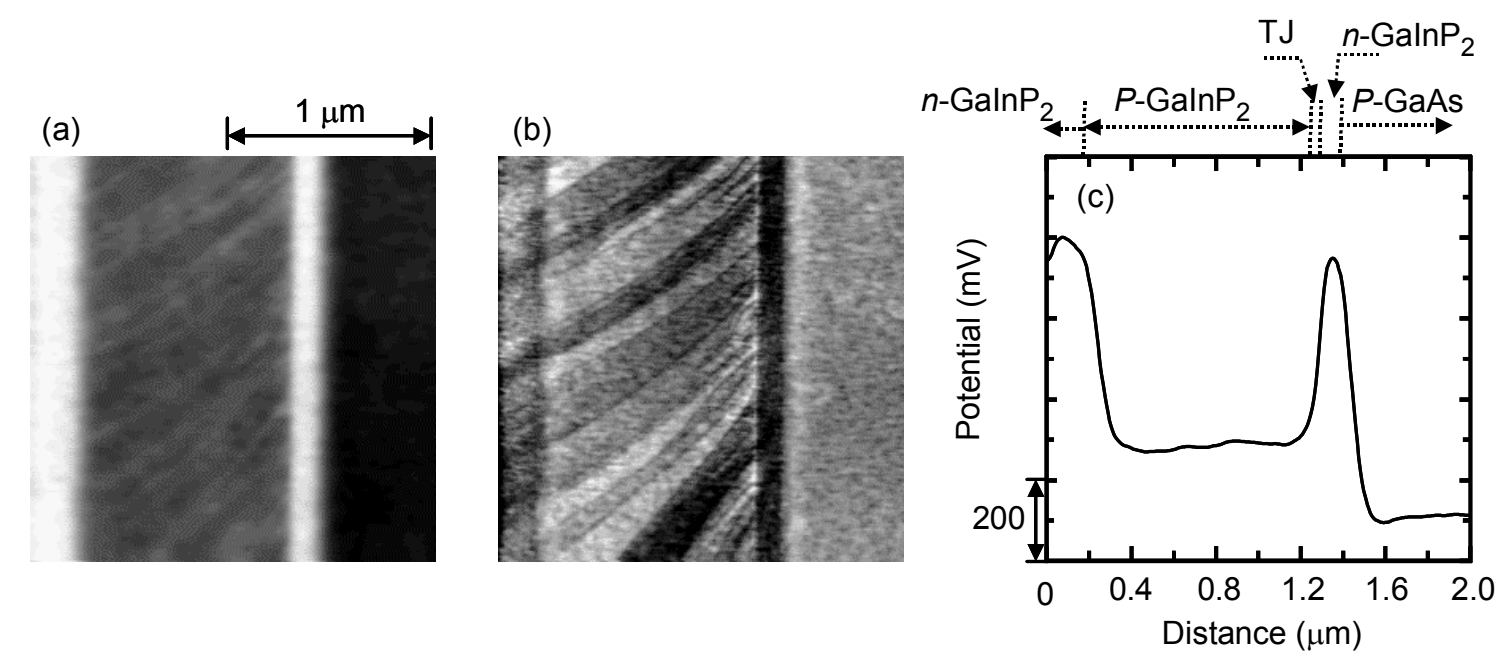

Fig. 2. (a) An SKPM potential and (b) the corresponding AFM topographic images taken on the cross-sections of $\mathrm{GalnP}_{2} / \mathrm{GaAs}$ tandem-junction solar cells. (c) shows the averaged potential profile along the vertical direction in Fig. 2(a). 
TABLE 1. Sizes and electronic properties of the multi-layers in the $\mathrm{GalnP}_{2} / \mathrm{GaAs}$ tandem cell.

\begin{tabular}{|c|c|c|c|c|c|c|c|}
\hline & Name & Material & Type & $\begin{array}{l}\text { Thickness } \\
(\mathrm{nm})\end{array}$ & $\begin{array}{l}\text { Doping } \\
\left(\times 10^{17}\right)\end{array}$ & $\begin{array}{l}\mathrm{Eg} \\
(\mathrm{eV})\end{array}$ & $\begin{array}{l}\text { Electron } \\
\text { Affinity } \\
(\mathrm{eV})\end{array}$ \\
\hline \multirow{4}{*}{$\begin{array}{l}\text { Top } \\
\text { cell }\end{array}$} & Window & AllnP 2 & $\mathrm{n}$ & 25 & 10 & $2.35^{[9]}$ & $3.78^{[10]}$ \\
\hline & Emitter & GalnP 2 & $\mathrm{n}$ & 90 & 10 & $1.85^{[11,12]}$ & $4.01^{[13]}$ \\
\hline & Base & GalnP $_{2}$ & $p$ & 840 & 1 & 1.81 & $4.01^{[13]}$ \\
\hline & BSF & GalnP 2 & $p$ & 50 & 10 & $1.89^{[11,12]}$ & $3.93^{[13-15]}$ \\
\hline \multirow{2}{*}{$\begin{array}{l}\text { Tunneling } \\
\text { Junction }\end{array}$} & p-layer & GaAs & $p$ & 10 & 100 & $1.42^{[16]}$ & $4.07^{[16]}$ \\
\hline & n-layer & GaAs & $\mathrm{n}$ & 10 & 100 & $1.42^{[16]}$ & $4.07^{[16]}$ \\
\hline \multirow{2}{*}{$\begin{array}{l}\text { Bottom } \\
\text { cell }\end{array}$} & Emitter & GalnP 2 & $\mathrm{n}$ & 100 & 10 & $1.85^{[11,12]}$ & $4.01^{[13]}$ \\
\hline & Base & GaAs & $p$ & 350 & 1 & $1.42^{[16]}$ & $4.07^{[16]}$ \\
\hline
\end{tabular}

the tunneling junction is slightly larger than the GaAs bandgap because of the conduction band offset $(0.14 \mathrm{eV})$ between $\mathrm{GaAs}$ and the disordered $p^{+}-\mathrm{GalnP}_{2}$ backsurface-field (BSF) layer in the top cell. The potential drop in the bottom junction is close to the p-layer's bandgap (GaAs, $\sim 1.42 \mathrm{eV})$. Although the n-layer of the bottom junction has a bigger bandgap (GalnP $2,1.85 \mathrm{eV})$, it does not significantly affect the potential because the conduction bands are almost aligned $\left(\delta E_{c} \sim 60 \mathrm{meV}\right)$.

Comparing the measured profile in Fig. 2(c) with the
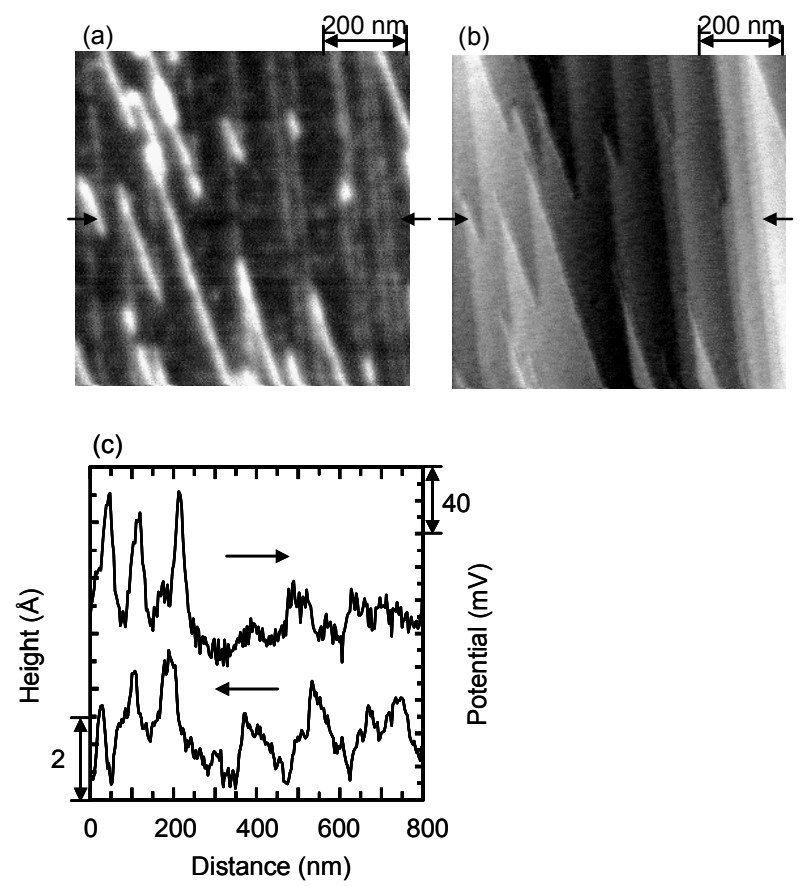

Fig. 4. (a) An SKPM potential and (b) the corresponding AFM topographic images taken on the cross-sections of GaAs substrate. (c) shows example line profiles along the arrows in (a) and (b). calculated potential profile in Fig. 3, we found that the measurement qualitatively agrees with the calculation. Values of the potentials at the junctions are smaller than the calculation. This discrepancy is due to the effect of surface Fermi level pinning. Although the sample is cleaved in UHV and is free of air molecule adsorption, defects on the surface can be responsible for the Fermi level pinning $[17,18]$. From the measured potential values, we can propose Fermi level positions in the bandgap [1]. However, the potential measurement can give us only relative values between the Fermi level positions in these epitaxial layers of the cell. To deduce the Fermi level pinning positions, at least one Fermi level position in the layers has to be known as a reference. For $\mathrm{GaAs}(110)$, various surface Fermi level positions were reported, possibly depending on the nature of surface defects and doping types [17-21]. Because the relative values of the potential measured by the UHV-SKPM is different from the values measured by the air-SKPM [1], the Fermi level pinning positions should be different between the UHV- and air-cleaved (110) surfaces, due to the air molecule adsorptions.

On the SKPM image [Fig. 2(a)], one sees bright lines in the absorber layer of the top cell, which correspond to steps, as shown in Fig. 2(b). These lines show $\sim 50-\mathrm{mV}$ higher potentials than on the terraces. The steps are single or a few atomic steps. The groove running along the tunneling junction is $\sim 1 \mathrm{~nm}$ in depth, and the step along the vertical direction in the top junction is $\sim 0.6 \mathrm{~nm}$ in height. The steps and the groove were created in the sample cleaving.

We also observed similar potential phenomena at atomic steps in the p-type GaAs substrate (Fig. 4), and found that the potential height depends on the step direction. To investigate the structure of the steps, we took STM images on the same sample area (Fig. 5). From the STM images, we know that there are angles between the atomic steps and the $[1 \overline{1} 0]$ direction. The 


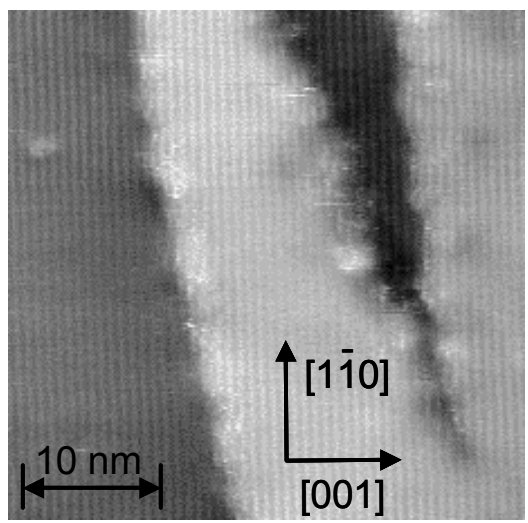

Fig. 5. A STM occupied-state image of the GaAs(110) surface taken in the same sample area as Fig. 4.

[110] direction is recognized by the atomic rows in Fig. 5. The steps in Fig. 4 are in two directions; the steps with the larger angle with respect to the [1 10$]$ direction show the larger potential $(\sim 100 \mathrm{mV})$ than do the steps with the smaller angle $(\sim 30 \mathrm{mV})$. All the steps are single atomic steps [Fig. 4(c)]. This dependence of the potential on the step direction may relate to anti-site or vacancy defects at the steps, because the unbalance of cation and anion concentration on the surface directly results in surface charges, which causes the electrical potential at the steps. A larger work function at the atomic steps than on the GaAs (110) terraces for a n-type GaAs was reported by Sommerhalter et al. [21].

\section{SUMMARY}

We have observed three electrical potentials at the top, tunneling, and bottom junctions of $\mathrm{GnInP}_{2} / \mathrm{GaAs}$ tandem-junction solar cells by performing the UHV-SKPM measurement. The effect of laser illumination was avoided by using a GaAs laser with photon energy of 1.4 $\mathrm{eV}$ for the AFM operation. We also observed higher potentials at the atomic steps than on the terraces for both the p-type GalnP $\mathrm{P}_{2}$ epitaxial layer and p-type $\mathrm{GaAs}$ substrate, and found that the potential at steps of the GaAs substrate depends on the step directions.

\section{ACKNOWLEDGEMENT}

This work is supported or funded under DOE Contract No. DE-AC36-99GO10337.

\section{REFERENCES}

[1] C.-S. Jiang, H. R. Moutinho, D. J. Friedman, J. F. Geisz, and M. M. Al-Jassim, J. Appl. Phys. 93, 10035 (2003).
[2] C.-S. Jiang, D. J. Friedman, J. F. Geisz, H. R. Moutinho, M. J. Romero, and M. M. Al-Jassim, Appl. Phys. Lett. 83, 1572 (2003).

[3] C.-S. Jiang, F. S. Hasoon, H. R. Moutinho, H. A. AlThani, M. J. Romero, and M. M. Al-Jassim, Appl. Phys. Lett. 82, 127 (2003).

[4] C.-S. Jiang, H. R. Moutinho, M. J. Romero, M. M. AlJassim, Y. Q. Xu, and Q. Wang, Thin Solid Films 472 , 203 (2005).

[5] C.-S. Jiang, H. R. Moutinho, Q. Wang, M. M. AlJassim, B. Yan, J. Yang, and S. Guha, Mat. Res. Soc. Symp. Proc. 808, 587 (2004).

[6] C.-S. Jiang, M. J. Romero, et al., unpublished.

[7] J. M. R. Weaver and D. W. Abraham, J. Vac. Sci. Technol. B9, 1559 (1991).

[8] A. Kikukawa, S. Hosaka, and R. Imura, Appl. Phys. Lett. 66, 3510 (1995).

[9] D. P. Bour, J. R. Shealy, G. W. Wicks, and W. J. Schaff, Appl. Phys. Lett. 50, 615 (1987).

[10] S. -H. Wei and A. Zunger, Appl. Phys. Lett. 72, 2011 (1998).

[11] S. R. Kurtz, P. Faine, and J. M. Olson, J. Appl. Phys. 68, 1890 (1990).

[12] A. Gomyo, T. Suzuki, and S. lijima, Phys. Rev. Lett. 60, 2645 (1988).

[13] J. Chen, J. R. Sites, I. L. Spain, M. J. Hafich, and G. Y. Robinson, Appl. Phys. Lett. 58, 744 (1991).

[14] S. Froyen, A. Zunger, and A. Mascarenhas, Appl. Phys. Lett. 68, 2852 (1996).

[15] J. J. O'shea, C. M. Reaves, S. P. Debaars, M. A. Chin, and V. Narayanamurti, Appl. Phys. Lett. 69, 3022 (1996).

[16] M. E. Levinshtein and S. L. Rumyantsev, in Handbook Series on Semiconductor Parameters Vol. 1, Edited by M. Levinshtein, S. Rumyantsev, and M. Shur (World Scientific, River Edge, NJ, 1996), p77

[17] Y. Ishikawa, N. Tsurumi, T. Fukui, and H. Hasegawa, J. Vac. Sci. Technol. B16, 2387 (1998).

[18] S. Aloni, I. Nevo, and G. Haase, Phys. Rev. B60, R2165 (1999).

[19] M. Kuball, M. K. Kelly, M. Cardona, K. Kohler, and J. Wagner, Phys. Rev. B49, 16569 (1994).

[20] K. J. Choi and J.-L. Lee, Appl. Phys. Lett. 74, 1108 (1999).

[21] Ch. Sommerhalter, Th. W. Matthes, Th. Glatzel, A. Jager-Waldau, and M. Ch. Lux-Steiner, Appl. Phys. Lett. 75, 286 (1999). 